https://dx.doi.org/10.4314/ijs.v22i3.16

Ife Journal of Science vol. 22, no. 3 (2020)

\title{
EVALUATION OF LEVELS OF SOME CARCINOGENIC METALS IN THE WATER AND INCIDENCES OF CANCER ALONG HADEJIA-JAMA'ARE RIVER BASIN AREAS
}

\author{
"Shaibu A.N and Audu A.A \\ Department of Pure and Industrial Chemistry, Bayero University, Kano - Nigeria \\ *Corresponding Author: E-mail: abdullahishaibu32@yahoo.com \\ (Received: 6th August, 2020; Accepted: 28th November, 2020)
}

\section{ABSTRACT}

\begin{abstract}
The determination of levels of some carcinogenic metals in the water and incidences of cancer was carried out in ten different local governments along Hadejia-Jama'are River Basin Areas, using standard procedures. Arsenic content was determined using UV Spectrophotometer after diazotization and heavy metals by atomic absorption spectrophotometry after acid digestion. The numbers of cancer patients were obtained from the Cancer Register of the health institutions along the basin after obtaining ethical approvals from the health institutions. The mean arsenic (As), of the water ranged from $3.35-10.60 \mu \mathrm{g} / \mathrm{L}$, cadmium $(\mathrm{Cd}): 1.57-10.10$ $\mu \mathrm{g} / \mathrm{L}$, chromium (Cr): $40.30-250.00 \mu \mathrm{g} / \mathrm{L}$, nickel (Ni): $48.80-235.00 \mu \mathrm{g} / \mathrm{L}$ and lead (Pb): $19.50-38.20 \mu \mathrm{g} / \mathrm{L}$. The metal concentrations in the water samples were higher in the dry season than the wet season. ANOVA showed significant differences at $\mathrm{p}<0.05$ for $\mathrm{Cd}, \mathrm{Cr}, \mathrm{Ni}$ and $\mathrm{Pb}$. The cancer levels were determined by matching the concentration of the heavy metals from each local government with number of cancer patients in the local government along the river basin route. The cancer cases along the basin were Bunkure-13, Wudil- 16, Ajingi11, Ringim- 9, Taura- 8, K/Hausa- 10, Hadejia- 12, Jama'are- 3, Gashua- 14 and Nguru- 10. Using the principal component analysis (PCA) there was an excellent relationship between cancer burden and metal loads in the potable water of the basin while the hierarchical cluster dendrogram (HCD) analysis reveals that arsenic, chromium and cadmium may be the major contributors to cancer incidences along the basin.
\end{abstract}

\section{INTRODUCTION}

Water is vital to human existence and its importance in daily life makes it necessary that thorough physicochemical examinations be conducted on potable water sources (Shaibu and Audu, 2018). It is the most abundant chemical compound in the human body and other living organisms and dominates the earth taking approximately $70 \%$ of the surface.

Every living thing on earth needs water to survive and inadequate quantity and quality water have serious impact on sustainable development (Adewoye et al., 2013). Today human activities are constantly adding industrial, domestic and agricultural wastes to ground water reservoirs at an alarming rate (Adefemi and Awokunmi, 2010). The increased use of metal-based fertilizer in agricultural practices results in continued rise in concentration of metal pollutions in fresh water reservoir due to run-offs from farm lands (Ambiga and Anna, 2013).

Similarly, industrial processes such as tannery effluents when discharged untreated, damage the normal life of the receiving water bodies. When allowed to percolate into the ground will pollute the groundwater permanently and make it unfit for drinking, irrigation and domestic consumption (Rahmanian et al., 2015).

Khaled and Muhammad, (2016) reported that many metals form stable complexes with biomolecules, and their presence, even at low quantities, can be harmful to plants and animals. The problem of heavy metals entering the food chain requires systematic assessments to make timely decisions to avoid severe health effects because of the invisible mode of their toxicity (Mir et al., 2016). According to Lohdip, (2013), contamination of heavy metals in the aquatic environment has attracted global attention owing to their abundance, persistence and environmental toxicity

Industrial liquid effluents are one of the principal sources of heavy metals responsible for environmental pollution (Solomon et al., 2015). The wastewater from the treatment of hides and skin in industrial effluents contain high levels of 
metals, toxic chemicals and other undesirable substances. As such, among all the industrial wastes, tannery effluents are ranked among the highest pollutants (Umar et al., 2017). Tanneries have been found to discharge not only chromium as an inherent product of tanning process but also significant amount of $\mathrm{Zn}, \mathrm{Mn}, \mathrm{Cu}, \mathrm{Pb}, \mathrm{Cd}, \mathrm{Hg}, \mathrm{As}$, $\mathrm{Ni}, \mathrm{B}, \mathrm{Se}, \mathrm{Mo}$ as well as nitrogen and phosphorous in both organic and inorganic forms (Akan et al., 2009). The International Agency for Research on Cancer (IARC, 2012) has classified arsenic, chromium, mercury, cadmium, lead, nickel and others and their compounds, as carcinogenic to humans. According to Shaibu and Audu (2019) these heavy metals are abundant in the tannery effluents that discharge the effluents into the Challawa River that feeds the Hadejia-Jama'are River Basin.

When cells are exposed to carcinogens, free radicals are formed that try to extract electrons from other molecules in the body. These free radicals damage cells and affect their ability to function normally (IARC, 2012; WHO, 2015). Exposure to toxic metals is closely associated with the formation of free radicals, directly or indirectly, in living organisms (Mates et al., 2002; Jomova and Valko, 2011). The cumulative generation of free radicals, such as reactive oxygen species (ROS) and reactive nitrogen species
(RNS), is termed oxidative stress and induces a cellular redox imbalance, which is linked to cancer incidence (Valko et al., 2004; Valko et al., 2006).

In Nigeria, freshwater systems are directly threatened by human activities and stand to be further affected by anthropogenic climate change (Amah 2015). One of the main sources of this water in Nigeria is Hadejia-Jama'are river basin, which receives textile and tannery waste effluents from the Sharada and Challawa industries in Kano (Akan et al., 2007).

The research is aimed at determining the heavy metal load in the potable water and incidences of cancer along Hadejia-Jama'are river basin areas.

\section{MATERIAL AND METHODS}

\section{Study area}

Hadejia-Jama'are river basin area drains a catchment of about $45000 \mathrm{~km}^{2}$ in the land area before discharging into Lake Chad. It covers the North west states of Kano, Jigawa and North east states of Bauchi, Yobe and Borno with irrigation potential of between 87000 hectares and 125000 hectares. The main activities taking place in the basin are agriculture, fishing, livestock keeping and water supply (Shaibu, 2020). (Table 1) showed coordinates of the sample sites

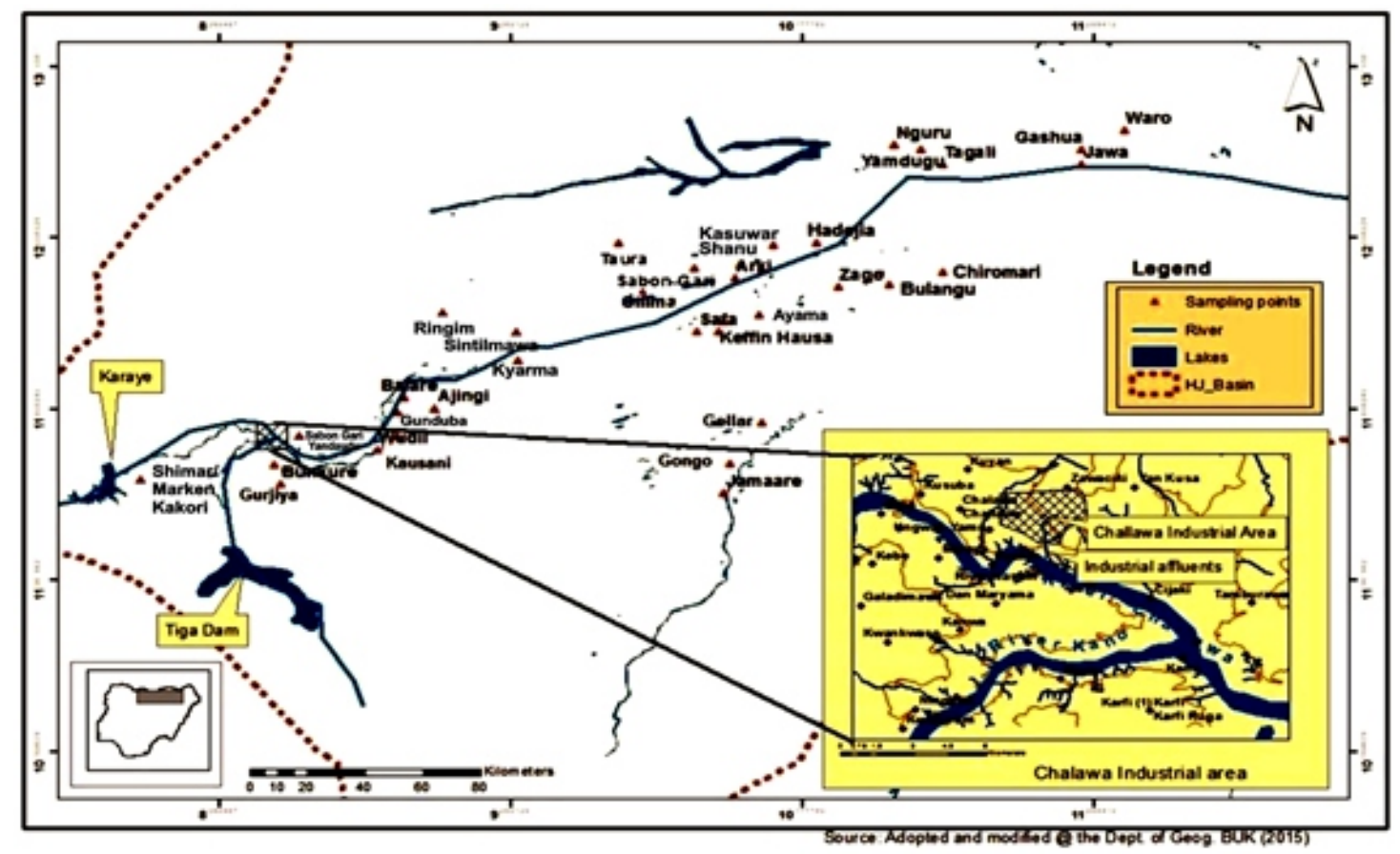

Figure 1: Map of the Study Area showing sampling sites 


\section{Sampling and Sample Pretreatment}

Water samples from Hadejia-Jama'are river basin area, 6 samples each were collected from 10 local government areas; Bunkure $[\mathrm{BKN}]$, Wudil
[WDL], Ajingi [AJN], Ringim [RGM], Taura [TAR], Kaffin-Hausa [KHS], Hadejia [HJA], Jama'are [JMR], Gashua [GSH] and Nguru [NGU].

Table1: Coordinate of the sample sites

\begin{tabular}{lll}
\hline Sample sites & Latitude & Longitude \\
\hline BKN & $11^{\circ} 34^{\prime} 2.0^{\prime \prime} \mathrm{N}$ & $8^{\circ} 26^{\prime} 36.0^{\prime \prime} \mathrm{E}$ \\
WDL & $11^{\circ} 48^{\prime} 33.73^{\prime \prime} \mathrm{N}$ & $8^{\circ} 50^{\prime} 20.52^{\prime \prime} \mathrm{E}$ \\
AJN & $11^{\circ} 58^{\prime} 6.0^{\prime \prime} \mathrm{N}$ & $9^{\circ} 2^{\prime} 12^{\prime \prime} \mathrm{E}$ \\
RGM & $12^{\circ} 9^{\prime} 14.37^{\prime \prime} \mathrm{N}$ & $9^{\circ} 9^{\prime} 34.99^{\prime \prime} \mathrm{E}$ \\
TAR & $12^{\circ} 15^{\prime} 20.38^{\prime \prime} \mathrm{N}$ & $9^{\circ} 23^{\prime} 2.72^{\prime \prime} \mathrm{E}$ \\
KHS & $12^{\circ} 11^{\prime} 23.23^{\prime \prime} \mathrm{N}$ & $9^{\circ} 55^{\prime} 26.96^{\prime \prime} \mathrm{E}$ \\
$\mathrm{HJA}$ & $12^{\circ} 27^{\prime} 12.49^{\prime \prime} \mathrm{N}$ & $10^{\circ} 02^{\prime} 28.14^{\prime \prime} \mathrm{E}$ \\
JMR & $12^{\circ} 17^{\prime} 6.25^{\prime \prime} \mathrm{N}$ & $10^{\circ} 21^{\prime} 0.97^{\prime \prime} \mathrm{E}$ \\
GSH & $12^{\circ} 52^{\prime} 2.99^{\prime \prime} \mathrm{N}$ & $11^{\circ} 02^{\prime} 28.20^{\prime \prime} \mathrm{E}$ \\
$\mathrm{NGU}$ & $12^{\circ} 52^{\prime} 26.99^{\prime \prime} \mathrm{N}$ & $10^{\circ} 27^{\prime} 5.39^{\prime \prime} \mathrm{E}$ \\
\hline
\end{tabular}

Samples were collected from each local government, from three points; 2 samples each from river bank, 10 meters away and midpoint using 4 litre cleaned plastic containers in dry and wet seasons. $1 \mathrm{~cm}^{3}$ conc. $\mathrm{HNO}_{3}$ was added to every 1L sample in $4 \mathrm{~L}$ container to maintain the stability of the oxidation state of the metals in solution (APHA, 2011; Anuo et al., 2012). One hundred and twenty (120) water samples in all were transported to the laboratory and subsequently used for the digestion. The samples for arsenic (UV/Visible spectrophotometer) analysis were collected separately in $2 \mathrm{~L}$ cleaned plastic containers and stored in the refrigerator.

\section{Digestion of Sample}

To digest the sample, $750 \mathrm{~cm}^{3}$ of the water sample was transferred into a $1000 \mathrm{~cm}^{3}$ pyrex glass beaker and evaporated on a hot plate. When the volume had reduced to about half the original volume, the remaining $250 \mathrm{~cm}^{3}$ was added and heating continued until the volume reduced to about $50 \mathrm{~cm}^{3}$. The solution was allowed to cool and $5 \mathrm{~cm}^{3}$ of concentrated nitric acid was added to the beaker and the content reconstituted with $30 \mathrm{~cm}^{3}$ of distill deionized water and heated on a hot plate at $85^{\circ} \mathrm{C}$ for few minutes. After a clear solution was obtained, it was allowed to cool and transferred into a $100 \mathrm{~cm}^{3}$ volumetric flask. It was then made up to $100 \mathrm{~cm}^{3}$ mark with distill deionized water and filtered into a $100 \mathrm{~cm}^{3}$ volumetric flask using Whatman 42 filter paper. The blank (distill deionized water) was prepared in a similar way by evaporating $1000 \mathrm{~cm}^{3}$ to $50 \mathrm{~cm}^{3}$ and subsequently digesting it using $5 \mathrm{~cm}^{3}$ concentrated nitric acid (Suleiman, 2015).

Each digested water sample was aspirated into the atomic absorption spectrophotometer (model: Varian AA240FS) and absorbance measured at the individual metal wavelength using the appropriate hollow cathode lamps of $\mathrm{Cd}, \mathrm{Cr}, \mathrm{Ni}$ and $\mathrm{Pb}$. Calibration curves for the different metals were generated from metal standard solutions and concentrations of metals were calculated. The results were obtained from the standard calibration curve.

\section{Determination of Arsenic Concentration in Water Samples}

To determine arsenic, $3.60 \mathrm{~cm}^{3}$ of water sample was pipetted into a test tube, $5.0 \mathrm{~cm}^{3}$ of ammonium molybdate-hydrazine mixture and 2 drops of $\mathrm{Na}_{2} \mathrm{~S}_{2} \mathrm{O}_{5}$ were added. To this mixture $1.0 \mathrm{~cm}^{3}$ of $\mathrm{KI}_{3}$ solution and $0.2 \mathrm{~cm}^{3}$ sodium hydrogen carbonate were added. This mixture was heated in a water bath at $95^{\circ} \mathrm{C}$. After cooling the absorbance reading was taken with UV-Visible 
Spectrophotometer (Jenway 6505) at ëmax $840 \mathrm{~nm}$. The concentration of metals was extrapolated from standard calibration curve (Sholadoye and Elias, 2016).

$4 \mathrm{~N}_{2} \mathrm{H}_{5}^{2+}+6 \mathrm{HAsO}_{4}^{2-} \rightarrow 4 \mathrm{~N}_{2}+3 \mathrm{As}_{2} \mathrm{O}_{3}+11 \mathrm{H}_{2} \mathrm{O}$

$+4 \mathrm{OH}^{-}------------$Equation 1

\section{Cancer Data Collection}

Application for ethical approval was written to all the major health institution around the study area. The approval was used to access the cancer register and the age, gender, address and part of the body affected were taken. The address of the individual cancer patient was used to correlate the cancer patient with the level of metals from the study area.

\section{Statistical Analysis}

All analyses were performed in triplicates and the results expressed as mean $\pm \mathrm{SD}$. The excel data analysis was used. The difference in $\mathrm{As}, \mathrm{Cd}, \mathrm{Cr}, \mathrm{Ni}$ and $\mathrm{Pb}$ concentrations among the different sampling points were tested by analysis of variance method, (ANOVA), a value of $p<0.05$ was considered statistically significant. Principal component analysis (PC) and Hierarchical cluster analysis were used to compare cancer, metals and sites.

\section{RESULTS AND DISCUSSIONS}

The Hadejia-Jama'are river basin water samples showed high arsenic levels in dry season than in wet season due to dilution in wet season (Tables 2 and 3). A significant difference was observed between the sites at $\mathrm{p}<0.05$. In the dry season, three of the sites, BKN, GSH and RGM have arsenic levels slightly above the WHO permissible limit (WHO 2008).

The principal component analysis (PCA), (Fig. 2) placed arsenic in component 1 with BKN, WDL, RGM, HJA and AJN. BKN was clustered with AJN and HJA by hierarchical cluster analysis dendrogram, Cluster F, (Fig. 3). The clustering of these sites may be due to their similarities in levels of As, 9.65-10.40; $7.45-9.22 ; 6.90-9.14 \mu \mathrm{g} / \mathrm{L}$, $\mathrm{Cd}, 2.73-7.87 ; 2.85-5.48 ; 2.70-5.54 \mu \mathrm{g} / \mathrm{L}, \mathrm{Cr}$, $165.00-190.00 ; 149.00-165.00 ; 132.00-133.00$ $\mu \mathrm{g} / \mathrm{L}$ with cancer incidences of 13.00, 11.00, 12.00 for BKN, AJN and HJA respectively. The PCA correlation chart (Fig. 4A) shows that arsenic, cadmium and chromium were positively correlated to cancer incidences with correlation coefficient, $r=0.359,0.419$ and 0.5347 respectively in dry season while contributions from $\mathrm{Ni}$ and $\mathrm{Pb}$ are very minimal as reveal by correlation chart (Fig. 4A and 4B). From the PCA analysis, arsenic cadmium and chromium may be the major contributor to cancer in these sites. This result is similar to the observations made by Aballay et al, (2012), Hamid et al, (2016), Mendez et al, (2017), and Steven et al, (2018) in which levels of As of $50.00 \mu \mathrm{g} / \mathrm{L}, 3.00-49.00 \mu \mathrm{g} / \mathrm{L}, 1.50-$ $15.40 \mu \mathrm{g} / \mathrm{L}$, and $1.00-950.00 \mu \mathrm{g} / \mathrm{L}$ respectively, in drinking water were found to have caused cancer among the inhabitants in their various study areas.

Table 2: Mean concentrations of Metals in the Water Samples in wet season

\begin{tabular}{lccccc}
\hline L.G & As $(\mu \mathrm{g} / \mathrm{L})$ & $\mathrm{Cd}(\mu \mathrm{g} / \mathrm{L})$ & $\mathrm{Cr}(\mu \mathrm{g} / \mathrm{L})$ & $\mathrm{Ni}(\mu \mathrm{g} / \mathrm{Lt})$ & $\mathrm{Pb}(\mu \mathrm{g} / \mathrm{L})$ \\
\hline BKN & $9.08 \pm 0.80$ & $2.73 \pm 0.60$ & $165 \pm 2.20$ & $87.7 \pm 0.90$ & $29.3 \pm 1.50$ \\
WDL & $9.65 \pm 1.00$ & $3.87 \pm 0.60$ & $224 \pm 2.40$ & $85.4 \pm 0.60$ & $31.9 \pm 0.90$ \\
AJN & $7.45 \pm 0.70$ & $2.85 \pm 0.70$ & $149 \pm 1.60$ & $109 \pm 0.90$ & $29.3 \pm 0.90$ \\
RGM & $9.65 \pm 0.90$ & $3.15 \pm 0.40$ & $144 \pm 1.60$ & $79.8 \pm 0.70$ & $32.8 \pm 0.80$ \\
TAR & $7.27 \pm 0.70$ & $2.62 \pm 1.00$ & $112 \pm 1.40$ & $112 \pm 1.50$ & $31.4 \pm 1.00$ \\
KSH & $7.05 \pm 0.60$ & $3.74 \pm 0.60$ & $111 \pm 1.60$ & $88.0 \pm 1.20$ & $22.8 \pm 1.30$ \\
HJA & $6.90 \pm 0.70$ & $2.70 \pm 0.40$ & $133 \pm 2.00$ & $96.6 \pm 0.60$ & $28.0 \pm 1.20$ \\
JMR & $3.35 \pm 0.30$ & $1.57 \pm 0.40$ & $40.3 \pm 1.00$ & $48.8 \pm 1.10$ & $19.5 \pm 0.70$ \\
GSH & $10.10 \pm 0.70$ & $6.55 \pm 0.50$ & $122 \pm 1.60$ & $95.2 \pm 1.30$ & $28.0 \pm 0.80$ \\
NGU & $7.13 \pm 0.70$ & $4.88 \pm 0.40$ & $123 \pm 1.80$ & $81.4 \pm 0.90$ & $30.5 \pm 1.30$ \\
WHO,2008 & 10.0 & 3.0 & 50.0 & 70.0 & 10.0 \\
\hline
\end{tabular}


Table 3: Mean concentrations of Metals in the Water Samples in dry season

\begin{tabular}{lllllc}
\hline L.G. & As $(\mu \mathrm{g} / \mathrm{L})$ & $\mathrm{Cd}(\mu \mathrm{g} / \mathrm{L})$ & $\mathrm{Cr}(\mu \mathrm{g} / \mathrm{L})$ & $\mathrm{Ni}(\mu \mathrm{g} / \mathrm{L})$ & $\mathrm{Pb}(\mu \mathrm{g} / \mathrm{L})$ \\
\hline BKN & $10.40 \pm 0.90$ & $7.87 \pm 1.30$ & $190 \pm 1.80$ & $107 \pm 1.80$ & $38.20 \pm 1.70$ \\
WDL & $9.80 \pm 1.00$ & $9.30 \pm 1.10$ & $250 \pm 2.40$ & $112 \pm 2.10$ & $30.20 \pm 1.80$ \\
AJN & $9.22 \pm 1.00$ & $5.48 \pm 1.10$ & $165 \pm 2.30$ & $120 \pm 2.40$ & $34.70 \pm 2.80$ \\
RGM & $10.20 \pm 1.00$ & $6.77 \pm 1.00$ & $186 \pm 1.00$ & $235 \pm 1.80$ & $36.50 \pm 2.00$ \\
TAR & $8.93 \pm 0.80$ & $7.43 \pm 1.10$ & $137 \pm 2.20$ & $122 \pm 2.00$ & $36.80 \pm 2.20$ \\
KSH & $9.32 \pm 0.80$ & $9.59 \pm 1.20$ & $117 \pm 2.00$ & $96.7 \pm 2.10$ & $24.40 \pm 1.80$ \\
HJA & $9.14 \pm 0.80$ & $5.54 \pm 0.90$ & $132 \pm 1.90$ & $111 \pm 2.00$ & $33.40 \pm 1.90$ \\
JMR & $4.20 \pm 0.60$ & $2.40 \pm 1.10$ & $44.4 \pm 2.00$ & $69.7 \pm 2.40$ & $21.10 \pm 2.30$ \\
GSH & $10.60 \pm 1.00$ & $10.10 \pm 1.50$ & $144 \pm 2.10$ & $111 \pm 1.50$ & $34.90 \pm 2.30$ \\
NGU & $8.95 \pm 0.80$ & $9.30 \pm 1.80$ & $136 \pm 2.10$ & $98.10 \pm 2.20$ & $36.30 \pm 2.10$ \\
WHO,2008 & 10.0 & 3.0 & 50.0 & 70.0 & 10.0 \\
\hline
\end{tabular}

The cadmium levels in GSH, NGU, KHS and WDL in the wet season were found to be above WHO limit of $3.00 \mu \mathrm{g} / \mathrm{L}$ and much higher in all the sampling sites in the dry season. The much increase in the levels in the dry season can be attributed majorly to the decreased volume of water in the basin (Ejieji et al, 2016). ANOVA of the results showed significant differences $(\mathrm{p}<$ 0.05) among the sites between wet and dry seasons.

The PCA placed cadmium in component 2 with KHS, GSH and NGU (Fig. 2) having correlation values positively correlated with cancer at $\mathrm{r}=$ 0.419 and 0.874 (Fig. 4A and 4B). This confirms that cadmium is the major contributor to cancer incidences in these three sites. From the cluster analysis (Fig. 3) KHS and GSH are in Cluster C due to their closer cadmium levels and number of cancers 10.0 and 14.0 respectively.

Cluster A contains only NGU, this is due to the fact that the levels of $\mathrm{Cd}$ in this site was relatively high $(4.88$ - 9.30) $\mu \mathrm{g} / \mathrm{L}$ above the WHO permissible limit of $3.00 \mu \mathrm{g} / \mathrm{L} \mathrm{Cd}$ and positively correlated with the cancer incidence level of 10.0 in the LGA. The cluster showed that the possible cancer cases in this area within the basin may be as a result of the levels of $\mathrm{Cd}$.

The result obtained is similar with the observations of Faijul (2013), Cd(10.00 - 30.00) $\mu \mathrm{g} / \mathrm{L}$; Nordberg (2010), Cd(25.00-50.00) $\mu \mathrm{g} / \mathrm{L}$; and Marouf (2018), Cd(25.00) $\mu \mathrm{g} / \mathrm{L}$ which were indicated in the breast, prostate and renal cancers among people that drank water with these cadmium levels in Bangladesh and in Iran.

The Hadejia-Jama'are river basin water samples have high chromium levels in both wet and dry seasons which were above the WHO maximum permissible limit of $50.00 \mu \mathrm{g} / \mathrm{L}$ in all the sampling sites except JMR (Tables 2 and 3).

The PCA placed chromium in component 1 (Fig. 2) with BKN, WDL, AJN, RGM and HJA. The correlation chart (Fig. 4A) showed that chromium was positively correlated to cancer in these sites at $r=0.585$ in dry season and this showed that chromium is the major contributor to cancer incidences at these sites. The cluster analysis placed BKN, AJN and HJA with Cr level (132.00190.00) $\mu \mathrm{g} / \mathrm{L}$ in the same cluster F (Fig. 3) as having similar cancer burden. This is similar to the observation of Cone (2009), where stomach and intestinal cancers were found among consumers of water with $57000 \mu \mathrm{g} / \mathrm{L}$ level of chromium.

The cluster analysis placed only WDL in Cluster D owing to its peculiarity in the high level of chromium (224.00-250.00) $\mu \mathrm{g} / \mathrm{L}$ and cancer incidences of 14.0, the highest in the basin indicating that $\mathrm{Cr}$ is the major contributor to cancer in site WDL. Similarly, RGM and TAR were placed in cluster $\mathrm{E}$ due to their similarity in agricultural activities and levels of metals load except for $\mathrm{Ni}$ where the level for dry season in RGM was much higher than TAR (Tables 2 and 3) and similar cancer burden of 9.0 and 8.0 respectively. 
The nickel concentration in the samples was above the WHO permissible limit of $70 \mu \mathrm{g} / \mathrm{L}$ for both wet and the dry seasons among all the sites. The PCA (Fig. 2) placed nickel in component 1 with very weak positive correlation to cancer at $\mathrm{r}=$ 0.190 (Fig. 4A) showing that nickel contributed minimally to cancer incidences in the study area.

Similarly, lead concentrations in the samples were found to be higher than the WHO permissible limit of $10.00 \mu \mathrm{g} / \mathrm{L}$ in both dry and wet seasons. The PCA analysis (Fig. 2) placed lead in component 1 with BKN, WDL, AJN, RGM and HJA. The contribution to cancer from lead is less as revealed by correlation value, $r=0.201$ as showed in (Fig. 4A).

Cluster B has JMR as the only site (Fig. 3) and has the least levels of metals though with high $\mathrm{Pb}$ $(19.50-21.10) \mu \mathrm{g} / \mathrm{L}$. These values were above the WHO maximum permissible limit of $10.00 \mu \mathrm{g} / \mathrm{L}$ and has cancer incidence of 3.0. Adamu et al,

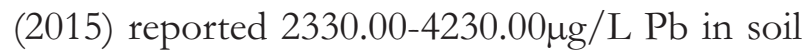
and water samples around the mining site in Jos metropolis, Plateau State Nigeria. The 3.0 cancer incidences may have come from lead. This is similar to the observation of Olusengun and Schrauzer, (2010) in which a breast cancer woman was found to have been consuming water with $500.00 \mu \mathrm{g} / \mathrm{L} \mathrm{Pb}$. The low levels of other metals apart from $\mathrm{Pb}$ in site JMR could be ascribed to the fact that the Jama'are River has it source from Jos, Plateau unlike the other sites that received their water from Challawa River (feeder river to the basin) with high pollution loads from tannery and textile effluents hence JMR served as control for this study.

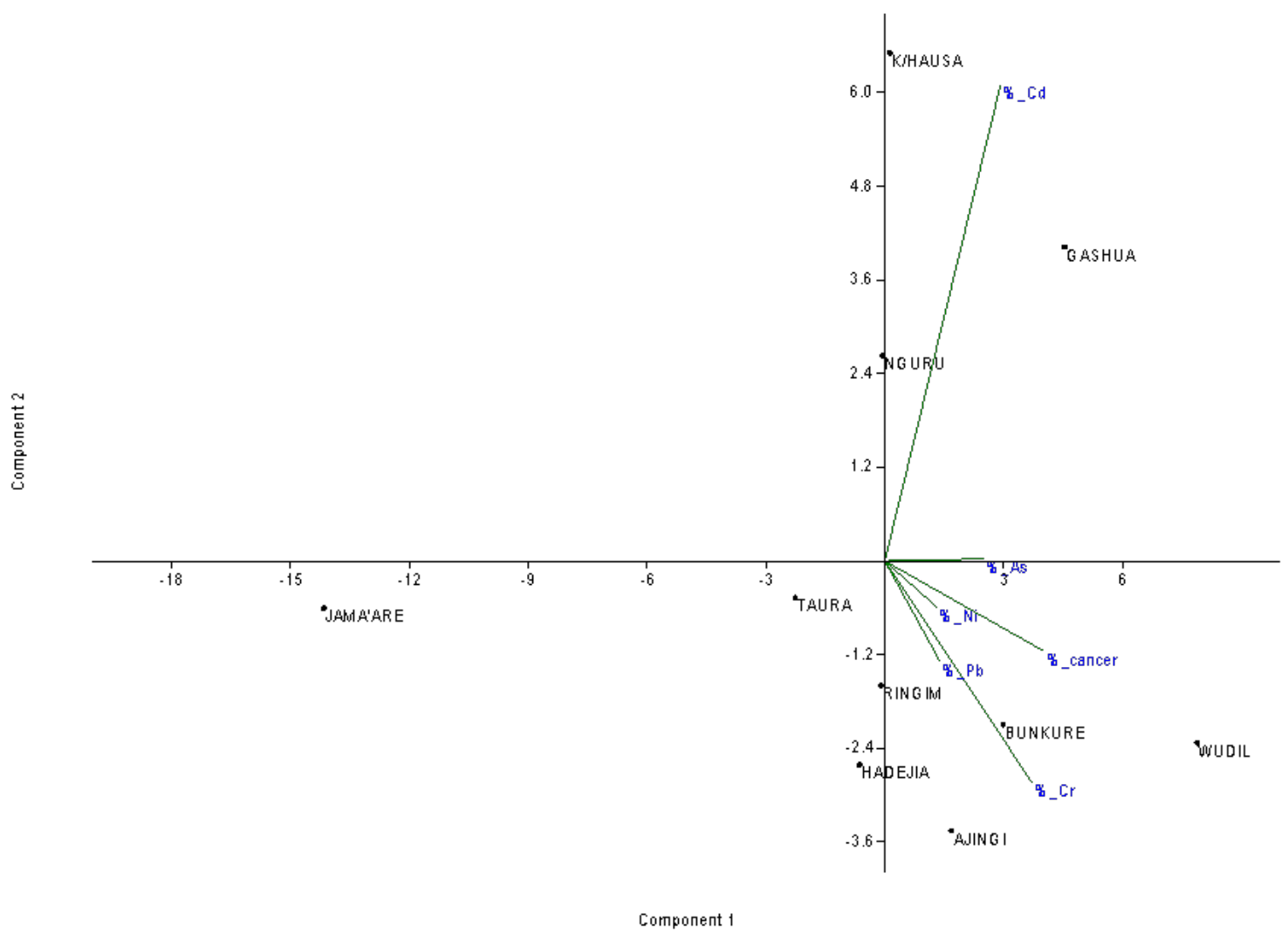

Figure 2: Principal Component Analysis of the Metals, Sites and Cancer Incidences 
D Islance

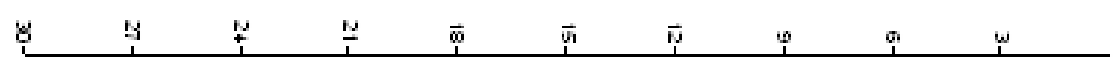

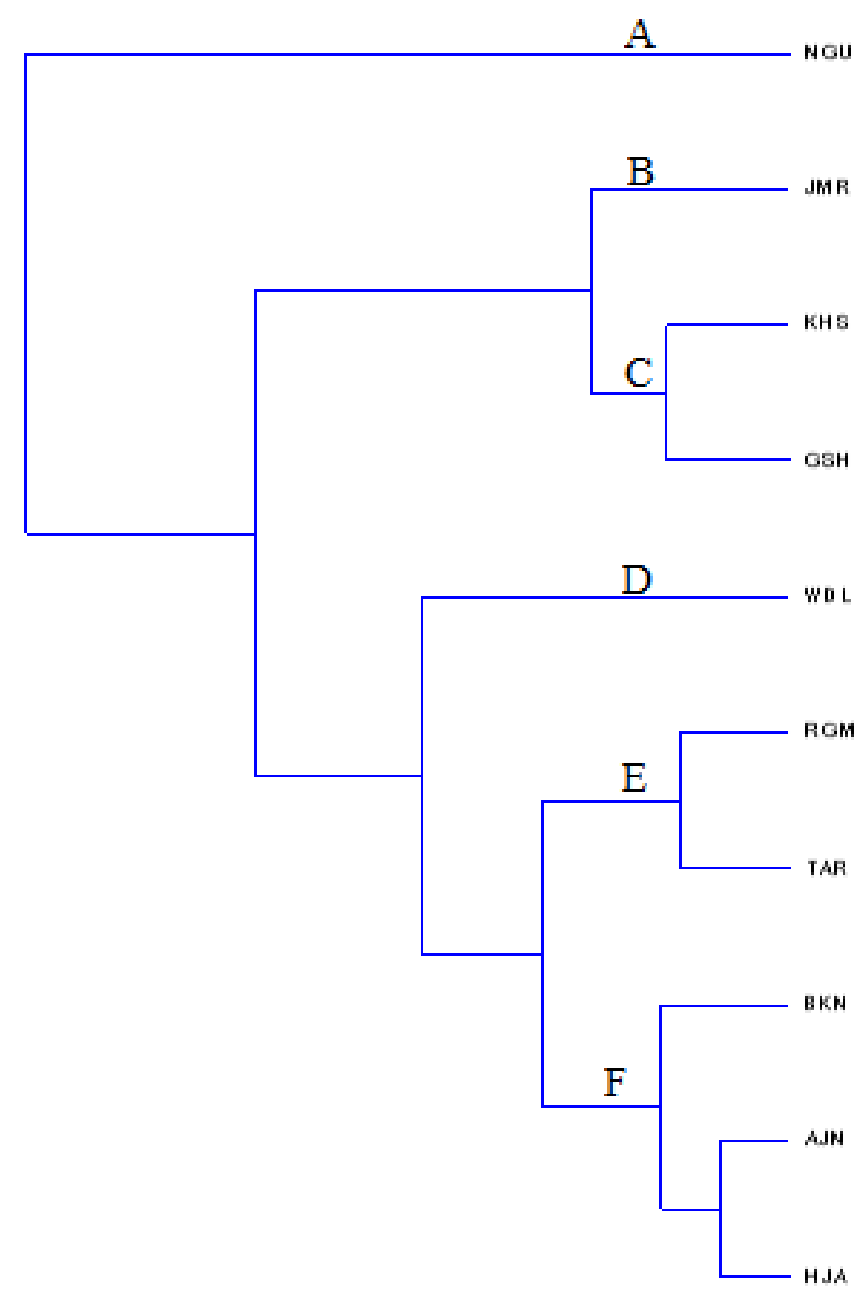

Figure 3: Hierarchical Cluster analysis dendrogram for Hadejia-Jama'are River Basin water sample.
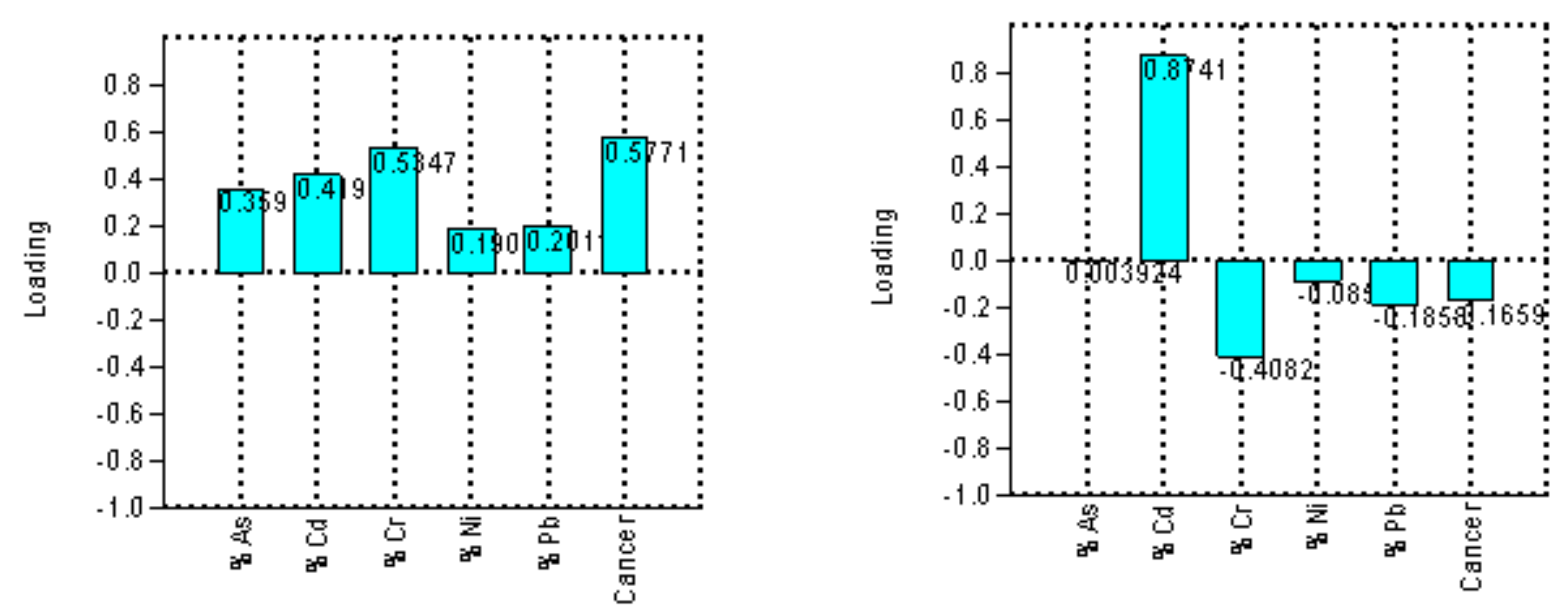

Figure 4: Principal Component Analysis Correlation chart

A: Dry season
B: Wet season 


\section{CONCLUSION}

From the results, it was observed that heavy metals present in the water samples of Hadejia-Jama'are river basin were higher in dry season than the wet season which may be due to dilution as the volume of water increases during wet season. The results also showed that these heavy metals are from industrial effluents discharged into the Challawa river that feeds the Hadejia-Jama'are basin by the Sharada and Challawa industrial estate. The PCA and cluster analysis have implicated the heavy metals in the incidences of cancer among the inhabitants along the basin as a result of the use of the water for agricultural and other domestic activities.

\section{REFFERENCES}

Aballay, L.R., Dia-Mmdel, P., Francisla, F.M. and Munoz, S.E. 2012. Cancer Incidences and pattern of arsenic concentration in drinking water wells in Cordoba, Argentina. Int. journal of Environmental Health Research 22(3):220-231

Adefemi, S. O. and Awokunmi, E. E. 2010. Determination of physico-chemical parameters and heavy metals in water samples from Itaogbolu area of OndoState, Nigeria. African Journal of Environmental Science and Technology. 4(3): 145-148.

Adamu, G.K., Muhammad, A., Abba, A.K and Haliru, J.L. 2015. Assessment of Heavy Metals in Soils and Surface Water around Mines in Jos Metropolis, Plateau State Nigeria. International Journal of Multidisciplinary Research and development. 12(2): 386-389.

Adewoye, S. O., Adewoye, A. O., Opasola, O. A. and Elegbede, J. A. 2013. Physicochemical Parameters and Heavy Metal Analyses of Water Samples from Hand Dug Wells in Gambari, Ogbomoso, Oyo State. Journal of Environmental Science, Toxicology and Food Technology, 5 (1): 22-30.

Akan, J. C., Ayodele J. T., Abdulrrahman, F. I. and Ogugbuaja, V. O. 2009. Impact of Tannery and textile effluents on the Chemicals Characteristics of Challawa Rive Kano State. Australian Journal of Basic and Applied Sciences, 3 (3): 1933-1947.

Akan, J. C., Ogugbuaja, V. O., Abdulrahman, F. I. and Ayodele, J. T. 2007. Determination of Pollutant Levels in Water of River Challawa and in Tap Water from Kano Industrial Area, Kano State, Nigeria. Research Journal of Environmental Sciences, 1:211-219.

Amah, J. I. 2015. Threats to Water Resources Development in Nigeria. Idu, Journal of Geology and Geophysics, 4(3): 1-10.

Ambiga, K. and Anna, D. R. 2013. Assessment of Groundwater Pollution Potential in and Around Ranipet Area, Vellore District, Tamilnadu. International Journal of Engineering and Science. 2(1):263-268

Anuo A. U., Egereomu, U. U. and Egereonu, J. C. 2012. Comparative Analysis of The Degree of Pollution of Okitankwo River along border Communites; Mbaitoli, Ikeduru, Emekuku, and Uratta of Imo State, Nigeria. Analytical science journal 1(1) 9-144.

APHA 2011: Standard methods for examination of water and wastewater; American Public Health Association. American Journal of Public Health $(\mathrm{AJPH}) 11^{\text {th }}$ edition, Academic, Pg 89-104. Washington, D.C.

Cone, M. 2009. Chromium in Drinking Water Causes Cancer. Environmental Health News. www.scientificamerican.com Accessed on 15/02/ 2017

Ejieji, C.J., Amodu, M.F. and Adeogun, A.G. 2016. Prediction of the Streamflow of HadejiaJama'are-Komadugu-Yobe River Basin, North Eastern Nigeria using Swat Model. Ethopian Journal of Environmental Studies and Management.9(2): 209-219.

Faijul, S. 2013. Too much Cadmium in Bangla rice. bdnews24.com, Accessed on 05/07/2016 at 9:00pm.

Hamid, F., Elisabeth, K. D., Nana, A. A. D., Ji, L., Rusan, C., Manning, F and Steven, H. L. 2016. Arsenic in Drinking Water and Lung Cancer Mortality in the United State: An Analysis on US Counties and 30years of Observation. Journal of Environmental and Public Health, Volume 2016, 13pages

IARC, 2012. Some drinking-water disinfectants and contaminants, including arsenic. Lyon, France, International Agency for Research on Cancer. (IARC monographs on the evaluation of carcinogenic risks to 
humans; vol. 84).

Jamova, K. and Valko, M. 2011. Advances in Metal-Induced oxidative stress and human disease. Journal of Toxicology. 283, 65-87.

Khaled, S. B. and Muhammad, A. A. 2016. Field accumulation risks of heavy metals in soil and vegetable crop irrigated with sewage water in western region of Saudi Arabia. Saudi Journal of Biological Sciences. 23: 32-44.

Lohdip, Y. N. 2013. River and stream water quality monitoring in North Central ZoneNigeria: Challenges and solutions. Proceedings of the 1 st Regional workshop organized by National water capacity building Network, North central Regional center. 1-9.

Marouf, B. H. 2018. Association between Serum heavy metals level and cancer incidence in Darbandikhan and Kalar Area, Kurdistan Region, Iran. Niger journal of Clinical Practice; 21:766- 771 .

Mates, J. M., Perez-Gomez, C., De Castro, I. N., Asenjo, M. and Marqueez, J. 2002. Glutamine and its relationship with intracellular redox status, oxidative stress and cell proliferation/death. International Journal of Biochemical and Cell Biology. 34, 439-458.

Mendez, W. M., Eftim, S., Cohen, J., Warren, I., Cowden, J., Lee, J. S. and Sams, R. 2017. Relationships between arsenic Concentrations in drinking water and Lung and bladder cancer incidences in US counties; Journal of exposure Science EnvironmentalEpidemiology 27:235-243

Mir, M. A., Mohammad, L. A., Saiful-Islam, M. D. and Zillur, R. 2016. Preliminary assessment of heavy metals in water and sediment of Karnaphuli River, Bangladesh. Environmental Nanotechnology, Monitoring \& Management. 5: 27-35.

Nordberg G. F., 2010. Biomarkers of Exposure, Effects and Susceptibility in humans and their application in Studies of Interactions among Metals in China. Toxicol Lett: 192, 45-49.

Olusegun, I. A. and Schrauzer, G. N. (2010). Lead Exposure: A Contributing Cause of the current breast cancer Epidemic in Nigerian women. Biological Trace
Element Research, vol136, 127-139.

Rahmanian, N., Siti-Hajar, B. A., Homayoonfard, M., Ali, N.J., Rehan, M., Sadef, Y. and Nizami, A. S. 2015. Analysis of Physiochemical Parameters to Evaluate the Drinking Water Quality in the State of Perak, Malaysia. Hindawi Publishing Corporation Journal of Chemistry. 1-10.

Shaibu, A. N. and Audu, A. A. 2018. Assessment of Physicochemical Parameters and Levels of Some Heavy Metals in the Potable Water of Hadejia-Jama'are River Basin Area. Journal of Chemical Society of Nigeria, 43(4): 802-816.

Shaibu, A. N and Audu, A. A. 2019. Evaluation of Physicochemical Parameters and some Heavy Metals from Tannery Effluents of Sharada and Challawa Industrial Areas of Kano State, Nigeria. Nigerian Journal of Basic and Applied Science. 27(2): 162-171.

Shaibu, A. N. 2020. Assessment of Physicochemical Parameters and Levels of some Heavy Metals in Sharada and Challawa Tannery Effluents and the Water of Hadejia-Jama'are River Basin Areas, Ph.D Thesis submitted to Department of Pure and Industrial Chemistry Bayero University Kano, unpublished.

Sholadoye, Q. O. and Nwoye, E. E. 2016. Heavy Metal Assessment in Portable Water Consumed in Offa Metropolis. International Journal of Novel Research in Physics, Chemistry and Mathematics 3(2)57-66

Solomon, S., Yadessa, C., Girma, T. and Daniel, F. 2015. Heavy Metal Concentrations and Physicochemical Characteristics of Effluent along the Discharge Route from Hawassa Textile Factory, Ethiopia. Journal of Environmental Analytical Toxicology, 5(4): 1-7.

Steven, H. L., Isabella, J. B., Hamid, F and Jaeil, A. (2018). Lung Cancer Risk and low $\leqslant$ $50 \mu \mathrm{g} / \mathrm{L})$ Drinking Water Arsenic Levels for US Counties - A negative Association. Int. Journal of Environmental Research and Public Health; 15; 1-21.

Suleiman, F. B. 2015. Physicochemical Analysis of Water and Sediment from some Dams in Katsina State, Ph.D Thesis submitted to Department of Pure and Industrial Chemistry Bayero University Kano, 
unpublished.

Umar, I. M., Ibrahim, M. A., Mustapha, M. B., Mohammed I. B., Obafemi U. T. and Ahmad G. I. 2017. Physicochemical Analysis and Microbiological Assessment of Tannery Effluent Discharged from Tanneries around Nigeria's Kano Industrial Estates. Journal of Advances in Microbiology, 2(1):1-12

Valko, M., Izakovic, M., Rhodes, C. J., Mazur, M., Tesler, J. 2004. Role of oxygen radicals in DNA damage and Cancer Induce. Journal of Molecular Cell Biochemistry 266, 37-56.

Valko, M., Rhodes, C. J., Mancol, J., Izakovic, M.,
Mazur, M. 2006. Free radicals, metals and antioxidants in Oxidative stress-induced cancer. Journal of Chemical, Biological Interaction. 160, 1-40.

WHO, 2015. Cancer Facts and Figures. Breast Carcinoma in Situ. American Canncer Society. Pg. 1-56. www.cancer.org/ .../ cancer-facts-and-figures-2015pdf.

WHO, 2008. Guideline for drinking water Quality.World Health Organization, Geneva. https://www.researchgate.net 